\section{THE 1984 DROUGHT ON THE CANADIAN PRAIRIES}

BY J. SWEENEY

St. Patrick's College, Maynooth, Co. Kildare

F ROM the beginning of Canadian settlement, the major challenge facing agriculture has been to adapt to the rigours of an extreme, and variable, climatic environment Nowhere is this struggle better epitomised than in the three Prairie Provinces of Albent. Saskatchewan and Manitoba. With annual precipitation amounts everywhere below, $500 \mathrm{~mm}$, and locally as little as $250 \mathrm{~mm}$, the climate of the Prairies can justifiably be described as semi-arid (Summerville 1981), and their vulnerability to even small departures from the climatic norm may be appreciated. Over large areas as little as $50 \mathrm{~mm}$ of rainfall can make the difference between abundance and economic crisis, particularly during late spring or early summer when the developing crops are in greatest need of moisture. This sensitivity was tragically demonstrated during the 1984 growing season. In the southern Prairies the 1984 grain harvest reflected some of the most adverse climatic conditions to have occurred since the notorious 'Dust Bowl' years of 1936 and 1937. Farmers in many parts of southern Alberta and southern Saskatchewan, the drought prone area known as the Palliser triangle, could only watch as a prolonged drought in association with record-breaking summer heat resulted in the loss of up to half of their grain crop. Often they also had to contend with a severe grasshopper infestation, hail damage, and dust storms reminiscent of the 1930s.

For the three Provinces as a whole, final harvest figures mask to some degree the difficulties experienced in the worst-affected areas. They also testify to the extent to which the Prairie farmer has learned to live with drought, improved farming techniques and irrigation enabling the yield fluctuations of former decades to be much reduced. Even so, substantial yield reductions were recorded in all six major grain crops compared with the previous year (Fig. 1). The year 1983 was itself unfavourable and, in the context of the previous five-year average, wheat (for example) showed a decline in yield of 17 per cent in 1984. This is the largest such drop since 1961 and such a departure from the previous five-year mean has only been surpassed on four other occasions since the 1930 s (Statistics Canada 1984).

WATER BALANCE COMPONENTS

Drought is a cumulative phenomenon and potential difficulties may often be anticipated in advance of the growing season. This may be best appreciated from an examination of the seasonal changes which occur in the soil moisture reservoir. Fig. 2 shows weekly estimates of precipitation, potential and actual evapotranspiration, and soil moisture status for Regina (Saskatchewan) over the period October 1982 to Septembe 1983.

No change in soil moisture status is observed during the winter, precipitation being in the form of snow which accumulates as a surface snowpack. Only after the spring thaw does this act to recharge soil moisture levels. This is of crucial importance for the agricultural economy, since it implies that snow cover during the preceding winter is the chief determinant of soil moisture reserves at the onset of the growing season. Through April and May 1983 moisture derived from both snowmelt and precipitation was adequate to satisfy the rising curve of potential evapotranspiration, and no depletion of soil moisture reserves occurred. At this time of year, particularly in the western Prairies, a relatively high water table is maintained as a result of snowmelt in the Rockies. By June, however, sources such as this are depleted and potential evapotranspiration demands are partially satisfied by the withdrawal of moisture from soil storage. Summer rainfal

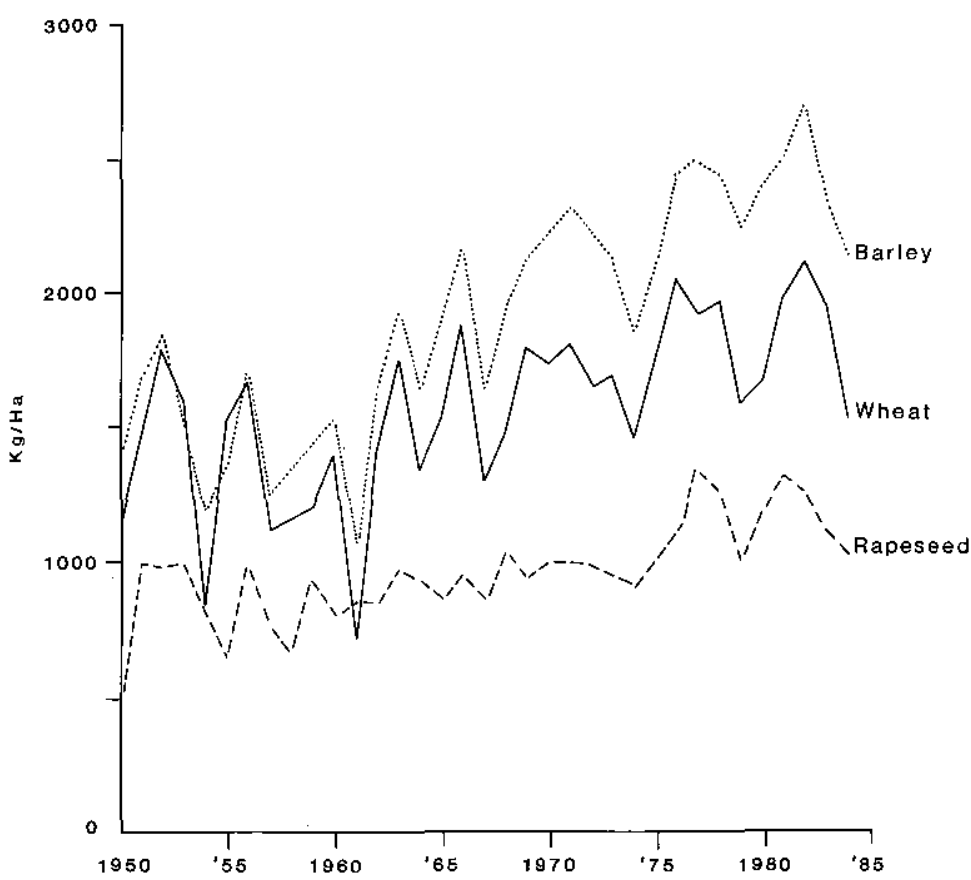

Fig. 1 Major grain vields in the Prairie Provinces 1950-84 (Source: Statistics Canada)

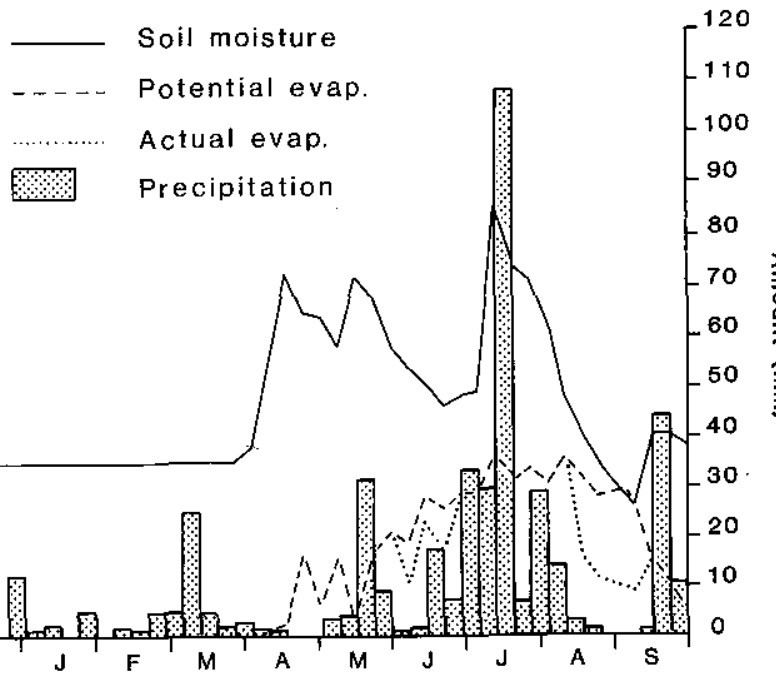

Fig. 2 Water balance components at Regina, Saskatchewan 
amounts are thus crucial in determining how severe soil moisture deficits become, and the extent to which moisture stress is exerted on the growing crop. Characteristically, defici persist, with differing degrees of severity, until the autumn rains exceed evapolicit demand, enabling recharge to occur in the soil. Rather ominously, in the case of Regine complete recharge had not occurred entering winter $1983 / 84$

Drought in the Prairies can thus be seen to stem either from a poor winter snow season, or from a failure of summer precipitation. For a severe drought both ingredien are necessary. Both had important roles to play in 1984

\section{THE CHRONOLOGY OF THE DROUGHT}

Summer 1983 had been one of the hottest summers in decades on the Prairies. Below normal rainfall and relentless heat (temperatures exceeded $40^{\circ} \mathrm{C}$ at some locations) mean that soil moisture reserves were already low by early autumn. It was therefore fairly critical even then that substantial winter snowfall occur if 1984 was not to be a difficult year.

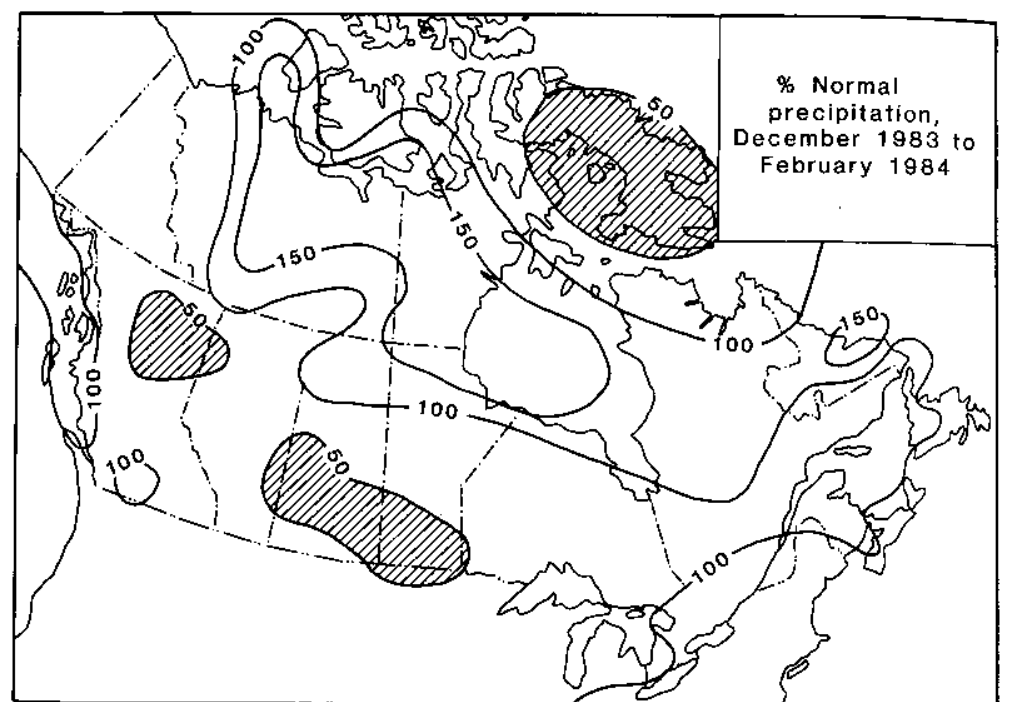

Fig. 3 Percentage of normal precipitation over Canada, December 1983 to February 1984

Winter 1983/84 proved extremely mild and dry. In the southern Prairies positive mean monthly temperature anomalies of 5-7 degC were common in January, and 6-11 degC during February (Environment Canada 1984). Lethbridge (Alberta), for example, had a maximum of $17.8^{\circ} \mathrm{C}$ on 5 February. On the same day Thompson (Manitoba) registered a minimum of $-41.3^{\circ} \mathrm{C}$, a figure more typical of the bitter cold which normally grips interior Canada at this time of year. Overall western Canada had one of its mildest winters in years, and its inhabitants enjoyed relatively low fuel bills.

Precipitation was, however, much reduced from normal, and amounts as little as $\mathbf{5 0}$ per cent of average were measured over wide areas, particularly in western Alberta and south-western Manitoba (Fig. 3). In the former area less than $1 \mathrm{~mm}$ of precipitation fell in February, making it the driest on record, while in the latter area only two drier winters had been experienced during the last 110 years. By early March, therefore, snowcover in many parts of the southern Prairies was nori-existent. Fig. 4 shows snowcover comparable with coastal British Columbia or the Maritime Provinces, a highly unusual occurrence. Only in the extreme north-east of the Prairies was there a water equivalent of over $100 \mathrm{~mm}$ storage in the snowcover. Such light snowcover at this time of year is normally confined southern Alberta where the Chinook enables cattle to forage for grazing outdoors iring winter.

With such deficient snowfall during the winter, spring runoff from the mountains was ell below normal. This prompted early concerns about low levels in stock watering les and ponds, and in the availability of sufficient irrigation water from rivers such as Oldman and Bow (Radomski 1984). Some alleviation was provided by mixed weather iring April and May, enabling sufficient soil moisture for germination of the newly wn grain crops. Late frosts, however, damaged these in many areas as late as mid-June. By midsummer the desiccated topsoil was blowing away, and significant soil erosion curred, in southern Saskatchewan. Dust storms with winds gusting up to $130 \mathrm{~km} / \mathrm{h}$ $0 \mathrm{kn}$ ) closed highways and indirectly caused several fatal traffic accidents. Some fields were reseeded several times in consequence, only to fall victim of that other hazard of hot, dry Prairie summers - the tornado. Throughout the summer the drought persisted. Less han half the seasonal average of precipitation was measured in large tracts of the southern

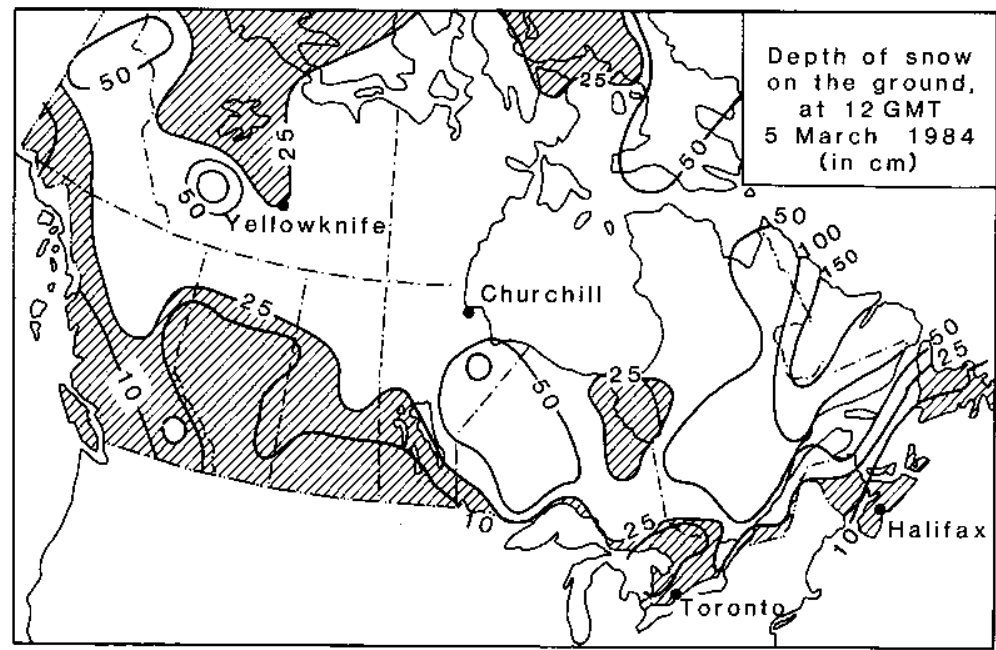

Fig. 4 Depth of snow on the ground at noon GMT on 5 March 1984

rairies and the moisture stress induced in the growing plants was further exacerbated by igh daytime temperatures. These commonly reached $38^{\circ} \mathrm{C}$ and many places had new ecord maxima established. Lethbridge (Alberta) recorded 36 successive days without heasurable rain during this excessively hot spell.

When precipitation did occur it was frequently as hail, and in late June golf-ballized hail in southern Manitoba devastated grains advanced in their growing cycle, such s. barley and rapeseed. Paradoxically, many farmers rejoiced in this destruction of their cop since the insurance payments staved off the spectre of bankruptcy which had been onfronting them. The warm, dry weather was also ideal for the proliferation of rasshoppers which by the end of July had eaten their way across $174000 \mathrm{~km}^{2}$ of crops. Showers in late summer came too late for crops on non-irrigated land. Some areas hich had avoided the worst of the drought, such as in the Peace River district of northern lberta, now succumbed to hail damage or excessively wet soil conditions which indered harvesting. By the end of September the first heavy snowfalls of the approaching inter had occured and killing frosts were reported everywhere, with temperatures as low $-12^{\circ} \mathrm{C}$ in Banff (Alberta). While auguring well for the recharge of soil moisture in 
spring 1985 , such conditions rapidly accelerated the deterioration of any unharvested crops from the 1984 season.

CAUSES - A SHORT-TERM PERSPECTIVE

Seasonal climatic anomalies reflect changes in the frequency with which particul airmasses are experienced. This in turn is controlled by the characteristics of the upperair circulation. In North America an important influence is exerted by the upperCordillera in obstructing the westerly flow, particularly at levels below $4000 \mathrm{~m}$. Unti they possess sufficient kinetic energy (or sufficient instability) to cross this barrier, low level westerlies are deflected northwards towards Alaska or southwards towards Mexico Most of the Pacific air which reaches the Canadian Prairies is thus air from higher levels in the westerlies (Bryson and Hare 1974). This air warms adiabatically, and its relative humidity decreases, as it descends the eastern slopes of the mountains. The stronger the westerly flow aloft, particularly between $40^{\circ}$ and $50^{\circ} \mathrm{N}$ where the mountain barrier more discontinuous, then the greater the penetration of mild Pacific air into continental interior. It is in such circumstances that the Prairies are mild and dry in winter, and hot and dry in summer.

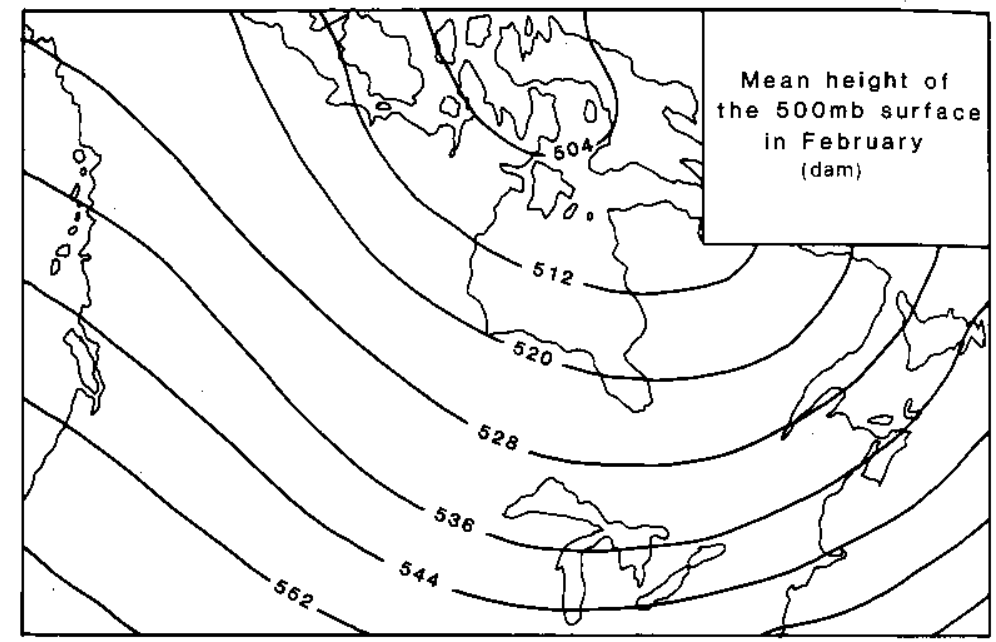

Fig. 5(a) Mean height of the 500mbar surface in February

The disturbance of the upper westerly flow is responsible for the system of downstream troughs and ridges which is apparent on time-averaged charts (Fig. 5a). Thi dynamical influence is further amplified in winter by thermal influences and the meridional flow pattern which restricts the invasion of mild Pacific air east of the Rockie and permits cyclonic disturbances formed in the lee of the mountains to swing southeastwards into the Prairies.

Although the early part of winter $1983 / 84$ followed this pattern, a marked departure was apparent by February (Fig. 5b). The normal ridge and trough development can be seen to be very restricted in amplitude and as a consequence the tropospheric flow is much more zonal over the continent. The relatively warm nature of these airstreams may be deduced by comparing the height of the $500 \mathrm{mbar}$ surface at similar locations on the average chart (Fig. 5a). Only those parts of Canada most removed from the south-west airstream had colder conditions than normal. In the waters east of Newfoundland, for example, ice cover was much more extensive than normal, while along the Labrador coas negative mean monthly temperature anomalies of $7 \mathrm{degC}$ were experienced in February (Gillingham 1984).
Over the Prairie Provinces a weak ridge can be discerned on Fig. 5b. This was a ire of much of the winter period and had the effect of suppressing cyclogenesis in the of the Rockies. Winter was therefore dry as well as exceptionally mild.

These features of the upper circulation became more accentuated during summer. warm ridge over the Prairies steadily grew in amplitude until by June it extended th and west to the Bering Strait. By this time it provided an effective block to the main serly current which was, in consequence, displaced southwards. Fig. 6 shows the flow, still highly zonal, located about $40^{\circ} \mathrm{N}$ and extending across the United States. interes developing in the westerly flow thus tended to pass south of the Prairies. relatively moist conditions existed in the greater part of the U.S. grain growing belt. ing to the north of the summer storm belt the Prairies were instead dominated by isiding, anticyclonic air which compounded the soil desiccation problems.

Such conditions mirror well those identified by Dey (1982) as drought-inducing. $y$ in one respect do they differ - the maintenance of the main westerly flow south, and north, of the Prairies. Had the latter occurred 1984 would have surely become a tinental scale drought of major proportions rather than one with acute regional impact

$$
\text { dily. }
$$

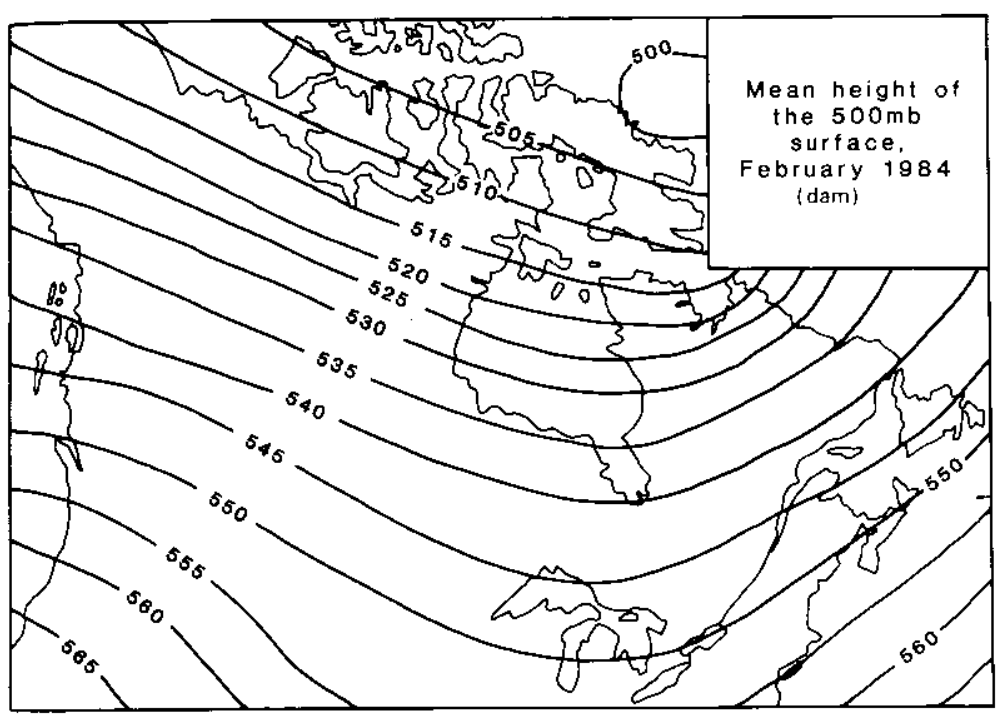

Fig. 5(b) Mean height of the 500mbar surface in February 1984

\section{CAUSES - A LONGER-TERM PERSPECTIVE}

The Prairies were settled primarily for strategic reasons, essentially to halt the prthward expansion of the U.S. open range cattle economy which threatened the political fisection of Canada (Gray 1967). In the border areas this settlement was against the dyice of the 1857 explorer Captain John Palliser who had claimed that the sparse and inreliable precipitation would never support viable agriculture. More optimistic counsels prevailed, however, largely on the basis of careful surveys carried out in the wetter $1870 \mathrm{~s}$ yi Professor John Macoun, and between 1896 and 1914 the Dominion Government llocated, and the railway companies sold, many millions of hectares of homestead land (Gray 1967).

The contrasting appraisals of Prairie potential in these early surveys reflect the 

'Jekyll and Hyde' nature of the climate. In the good years the diaries of the early settle
and fur traders chronicle the bountiful harvests, as e.g. in 1869: 'Never before have the crops looked better than they have this summer. In many
instances the wheat is six feet in height' (Hope 1938).

When the west wind blew consistently, however, the bad years, came (Bochart 1950) a the hardships endured by the small communities is similarly recorded, e.g. in 1891:

'In many places grasshoppers were three inches deep and could be shovelled with a spade. Even the leaves and bark were stripped from trees'.

And in 1868:

$\therefore$. . early in August an earnest appeal for aid for the virtually starving population was addressed to Canada, England and the U.S.' (Hope 1938).

The tendency for drought recurrence intervals to average 20-23 years was noted by Weakly (1943), and later by Thomas (1962), though this was not linked with solar cycles until the resurgence of interest in solar-climate relationships in the 1970s. However, while Mitchell et al. (1979) were able to establish a linkage between a drought index for the U.S. Great Plains and the 22-year sunspot cycle, other studies have not confirmed this. Kart and Koscielny (1982) and Schneider (1978) have emphasised the need to establish a physical basis for such a link, perhaps along the lines of that suggested by Olson et al (1975) and Schuurmans (1979) who relate solar flare activity to short term perturbations in the atmospheric circulation, such as increased cyclonic activity in the mid-latitudes. Such a relationship between enhanced zonal flow (which promotes drought on the Plains and Prairies) and solar cycles may thus be a reality, and the 1984 drought seen in th context.

\section{THE COST OF THE DROUGHT}

Quantifying the monetary cost of drought is a complex exercise fraught with difficulties because of the nature of the drought phenomenon. Some effects such as crop failure may be immediately evident, while others, such as soil deterioration, are more long-term in nature. Similarly some impacts (such as income losses suffered by farmers) can be directly calculated, while others (such as the loss of spending power in the regional economy) may only be estimated indirectly. Drought, however, has major economic ramifications. Karl and Quayle (1981) suggested total economic losses of \$16B as a consequence of the 1980 drought in the U.S. Great Plains. For the same year, Fraser (1981) estimated the cost of the drought on the Canadian Prairies to be $\$ 2-2.5 \mathrm{~B}$. This drought produced a production drop of about ten per cent for the six major grain crops from the previous five-year average, somewhat less than the 1984 drought. A figure in excess of $\$ 2.5 \mathrm{~B}$ may thus tentatively be placed on the 1984 drought

REFERENCES

Bochart, J. R. (1950) The climate of the Central North American grassland. Annals Association of American Geographers, 40, pp. 1-39

Bryson, R. A. and Hare, F. K. (1974) Climates of North America. Elsevier Press, Amsterdam Dey, B. (1982) Nature and possible causes of droughts on the Canadian Prairies - case studies Journal of Climatology, 2(3), pp. 233-249

Fraser, H. M. (1981) Economic and social effects of the 1980 drought on the Prairies. In: Phillips, D. W. and McKay, G. A. (Eds), Canadian Climate in Review: 1980, Environment Canada Minister of Supply and Services, Ottawa

Gillingham, A. (1984) Ice cover-eastern Canadian waters: winter and early spring 1983-84 Climatic Perspectives, 6, (Monthly Supplement April 1984), pp. 8-10

Gray, J. H. (1967) Men Against the Desert. Modern Press, Saskatoon, Saskatchewan

Hope, E. C. (1938) Weather and crop history in western Canada. Canadian Society of Technica Agriculturalists Review, 16, pp. 347-353

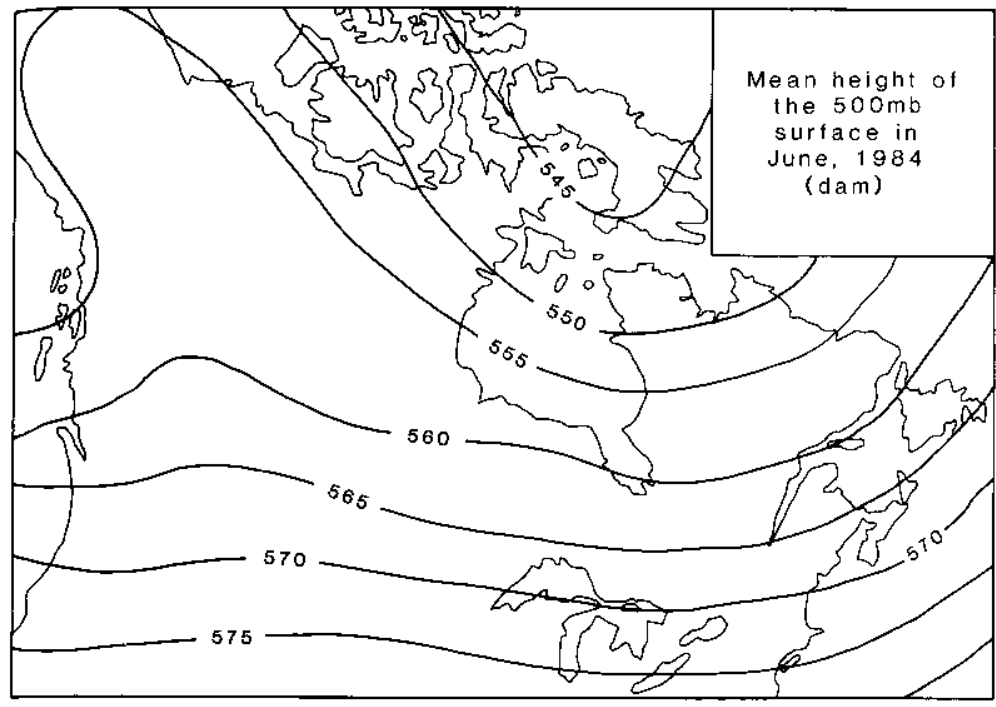

Fig. 6 Mean height of the 500 mbar surface in June 1984

T. R. and Koscielny, A. J. (1982) Drought in the U.S.: 1895-1981. Journal of Climatolog. 2(4), pp. 313-330

T. R. and Quayle, R. G. (1981) The 1980 summer heat and drought in historical perspective. Monthly Weather Review, 109, p. 2055

ie, P. Y. (1984) The climatic water balance. Climatic Perspectives, 6, (Monthly Supplement June), pp. 5B-6B

hell, J. M., Stockton, C. W. and Meko, D. M. (1979) Evidence of a 22-year rhythm of drough in the western United States related to the Hale solar cycle since the 17th Century. In McCormac, B. M. and Seliga, T. A. (Eds). Solar Terrestrial Infliences on Weather and Climate, D. Rcidel, Dordrecht, Netherlands

n, R. H., Roberts, W. O. and Zerefos, C. S. (1975) Short-term relationships between solar flares, geomagnetic storms and tropospheric vorticity patterns. Nature, 257, pp. 113-115 $5 \mathrm{~A}$

A A American Droughts. Westview Press, Boulder, Colorado

urmans, C. J. (1979) Effects of solar flares on the atmospheric circulation. In McCormac, B M. and Seliga, T. A. (Eds). Solar-Terrestrial Influences on Weather and Climate. D. Reidel Dordrecht, Netherlands

bbar, A. (1984) Winter of '83-84 - a review. Climatic Perspectives, 6, (Monthly Supplement February), pp. 8B-9B

istics Canada (1984) Supply and disposition of wheat coarse grains and oilseeds. Canada Prairie Provinces. Cereals and Oilseeds Review, Statistics Canada, Minister of Supply and Services, Ottawa

merville, S. (1981) Heat and drought 1930s style. Chinook, 4(1), pp. 10-1l

mas, H. E. (1962) The Meteorologic Phenomenon of Drought in the South West. U.S. Geological Survey, Professional Paper 342A, Washington

kly, H. E. (1943) A tree ring record of precipitation in western Nebraska Journal of Forestry 41, pp. $816-819$ 